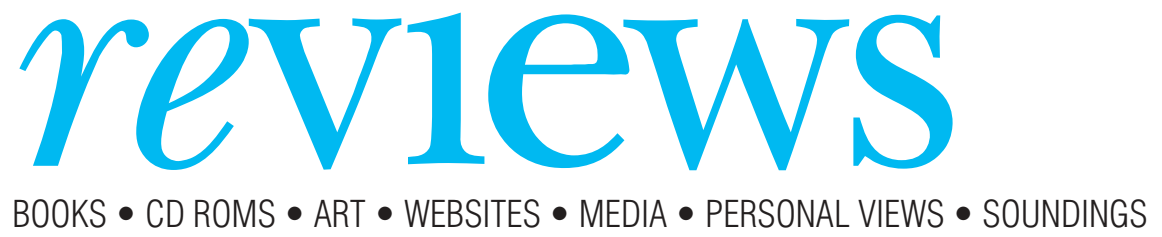

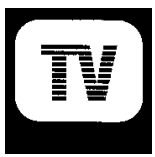

\section{Human Mutants}

Channel 4, Thursdays at 9 pm from 3 to 17 June

\section{Rating: $\star \star \star$}

$\mathrm{F}$ ull marks for the attention grabbing title. But I suspect that anyone looking forward to a Victorian style freak show would have been frustrated. Admittedly, Human Mutants does have most of the key ingredients-mysterious lighting, a spooky ringmaster, giants, dwarves, and babies in bottles. But for the voyeur craning his or her neck in the front row, all the serious science and compassion would get in the way. This is about how deformity reveals normality, and how we are all mutants-it's just that some of us are more mutant than others.

Our ringmaster, self confessed mutant Armand Leroi, is in fact a reader in evolutionary developmental biology at Imperial College, London. His series champions the contribution that the study of mutation has made to science's understanding of human development and evolution. In the first programme, "The Mystery of Growth," he showed us how we grow and what happens when that complex growth mechanism goes wrong.

The opening sequence was an acknowledgement that the study of mutants has had

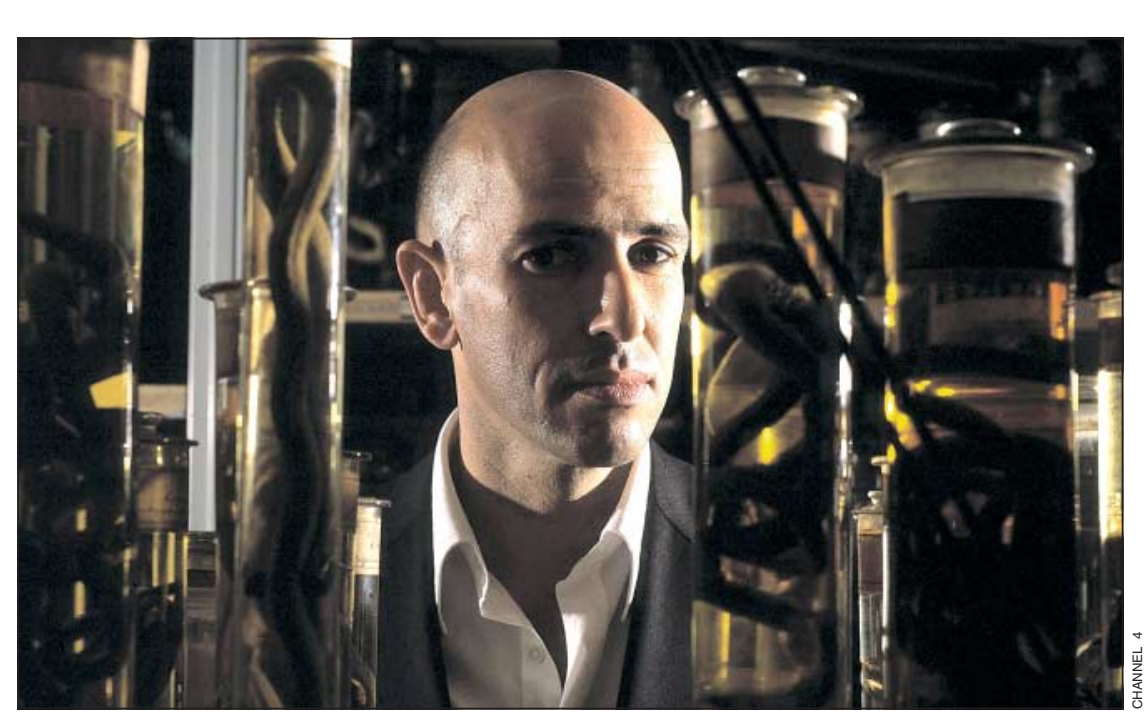

Spooky ringmaster: series presenter Armand Leroi

a deeply dark side. It was a moody reconstruction of the moment in May 1944 when a family of dwarves, the Ovitz family, was herded into Auschwitz in a cattle car. Transylvanian Jews, they were saved from the gas chambers only to be experimented on by the "Dark Angel of Auschwitz," Josef Mengele, who was obsessed with knowing why their limbs were so short and bowed. As the programme went on, we heard how Mengele bled them till they fainted, $\mathrm{x}$ rayed them, and carried out repeated gynaecological examinations on the women. All "brutal, fathomless experiments that were incapable of revealing anything about growth," said Leroi.

The emphasis, though, was on the more fruitful-not to mention legal-aspirations of modern science. Leroi introduced us to Chris Greener, at 2.29 metres the tallest man in Britain. He seemed a jolly chap, chuckling at how children often pointed at him in supermarkets and said, "Look, Mum-there's a giant." The science kicked in with a basic explanation of how Chris's overactive pituitary had made him so tall. By the 1940s, when Mengele was busy brutalising the Ovitz family, science had already established the role of pituitary hormones in growth.

In Cape Town, Leroi talked to some of the thousand or so people there who have Arnold's syndrome, which can leave them with bulging foreheads, pointed faces, holes in their skulls, and partial or absent clavicles. They are all descendants of one 19th century sailor called Arnold and we now know that they carry a mutation in a gene that "switches genes on and off in cells that

BMJ VOLUME 328 5 JUNE 2004 bmj.com make bone." As one of Arnold's descendants pointed out, you can often spot other people with the syndrome in the street-a great way to keep in touch with the relatives.

There was a "macabre display" of fetuses in bottles (nothing that doctors won't have seen in the path museum) to introduce mesoderm, chondrocytes, and osteoblasts. We met a woman with the rare genetic condition fibrodysplasia ossificans progressiva (FOP), where bone growth replaces muscle, tendons, and ligaments. Leroi explained why our understanding of the role of bone morphogenetic protein in FOP could help thousands of people with bone disorders. And there was a fascinating account of the castrati, the male singers who lost their testicles before puberty. A modern mezzosoprano described the castrato as the Jennifer Lopez of the 18th century opera halls. Castrati were a lot bigger than J-Lo, though-they became so huge because their bone growth zones stayed open because of a lack of testicular oestrogen.

Leroi's tour ended with a visit to a conference of the Little People of America, "where the West's dwarves come to meet and mate." The Little People-with many of the 20 or so dwarf conditions such as achondroplasia, pituitary dwarfism, and pseudo-achondroplasia-told us why they didn't mind being called dwarves or little people, but midget was not acceptable. The scientific point was that in the past 10 years, the mutations responsible for nearly all forms of dwarfism had been identified. We even know, said Leroi, the very thing that eluded Mengele-why the Ovitz family were small. They had pseudo-achondroplasia, and the gene responsible was discovered by science 50 years after their Auschwitz ordeal.

Human Mutants is a brave attempt to explain what scientists and doctors know already: that science often learns from the limits of humanity. It is more a celebration of diversity than a freak show. The next two programmes are equally absorbing: "Making Babies" looks at the origins of order in the womb, including Cyclops babies and "real-life mermaids" (sirenomelia); and "Skin Deep" tackles issues of skin colour, race, and hairy-faced families. They could have called the series "The science of human development"-but I suspect that fewer people would watch it. And that would be a shame.

Graham Easton assistant editor, BM geaston@bmj.com 


\section{Football Medicine}

Eds Jan Ekstrand, Jon Karlsson,

Alan Hodson

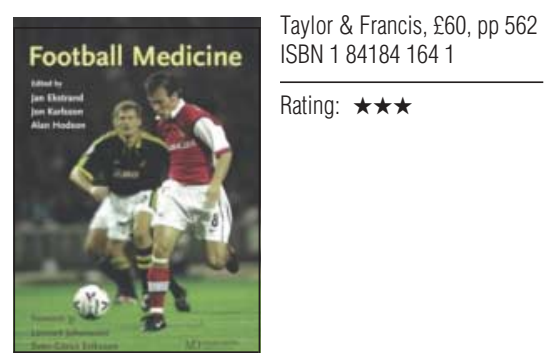

I did not need a second invitation to review a book entitled Football Medicine, two subjects dear to my heart-although my more cynical colleagues would no doubt say the former more than the latter. Aptly for a book of largely Swedish origin, and at the end of a historic unbeaten season for the mighty Gunners, their very own Freddie Ljungberg is in full flow on the front cover, although on a decidedly subdued hair day. The book's line up is impressive: forewords by Lennart Johansson, the president of the Fédération Internationale de Football Association, and the one and only Sven-Göran
Eriksson; and an extensive list of premiership quality contributors, including our own Alan Hodson, who should need no introduction to anyone interested enough to pick up a copy, and another adopted Swede, Leif Sward, our national team's doctor.

The authors have valiantly attempted to cover a range of important topics in a clear and readable manner, but much of it is simplistic, to the extent that I was left wondering exactly who the book is aimed at. The title would seem to target the medical profession, but even those, like myself, who consider themselves first and foremost general practitioners, with their footbal medicine (with or without club attachment) as a special interest, will find much of it frustrating, in that it whets the appetite but leaves you unsatisfied. This is particularly true of the 180 pages on sports injuries. The bonus is the sheer array of topics, including injury prevention (with some interesting statistics), post-injury rehabilitation and testing, biomechanics, physiology, nutrition, foreign travel, and even, at the end (against naval etiquette), women and children.

Whether something has been lost in translation I am not sure, but although it's a stress free read the overall pace and tone are decidedly Sven: informative, polite, and charming, but dry to the point of monotone, with scarcely a word wasted in anger. It's almost a caricature of your average Briton's perception of your average Swede.

Should doctors without a special interest buy this book? I don't know. As an introductory text it is certainly suited to professionals wishing to familiarise themselves with the essentials of the subject. Would nonmedically trained people benefit? Only if they have a passing interest and wish to know more. Anyone who has trained or is training in physiotherapy, nutrition, or sports science and so on would need more specialised information.

As with wine and golf I enjoy everything I read on the subject, and this book was no exception. It whiled away many a journey and many a hotel stay and provided relief from the interminable chewing of nails entailed in the relentless quest for premiership safety points. Well, Freddie, we're coming to do it all again-but will you get another standing ovation next season?

Nigel Sellars general practitioner, Woking, Surrey (and club doctor at Portsmouth Football Club)

NigelMaura@AOL.com

\section{Child Public Health}

Mitch Blair, Sarah Stewart-Brown, Tony Waterston, Rachel Crowther

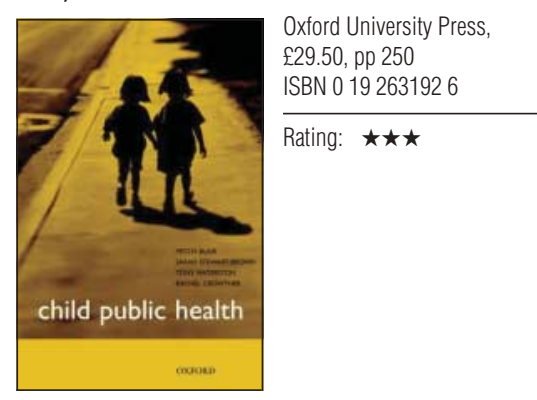

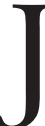
ust as the HIV and AIDS epidemic turned the curiously unsexy specialty of genitourinary medicine into primetime television and ratcheted sexually transmitted infections up the scientific agenda, current policy interest in child public health means that this book is coming out at just the right time to persuade students that what used to be thought of as a backwater of baby clinics, bad kids, and nits is not just important but fun. They can make a difference to children's and adult health, make friends and allies outside medicine, and have a role in social and public policy.

Child public health-encompassing as it does work in health, welfare, education, housing, and public policy-is potentially the most effective activity we can engage in to improve outcomes for children and the adults that they will become. The evidence that investment now will yield wide ranging returns later has made the field politically attractive. This book gives an overview of child health in the United Kingdom and internationally, the founding fathers (those listed are all men), the epidemiology, the data sources, the policies and politics, and the interventions.

The history and the international picture that the authors present reminder us of how far we have come. The comparison with Scandinavian countries (curiously, in the United Kingdom we are more inclined to look to North America than Scandinavia for solutions) and the shocking differences across social classes for almost all causes of death among British children indicate how far we still have to go. If some of the ills associated with poverty, including injuries to pedestrians, had been contagious, those elements of child public health unconnected with immunisation, sewers, and drains might have been taken more seriously sooner.

The development part of research and development has often been neglected in the non-commercial sector. Although the authors make a decent stab at looking at what works, the evidence base in child public health is smaller than it might be. Perhaps we now know enough about the determinants of health (in which the United Kingdom has an exceptionally strong scientific record) for more of the funding effort to be directed towards pulling together what we do know, for good quality primary studies and evaluations, and for better reporting on the problems, as well as the solutions, in implementation. We also need more evidence from lay people, and the authors draw attention to what children themselves have to tell us. As for parents however much effort goes into child public health, it is still likely to be parents and in particular mothers who do the lioness's share in this area. We can learn a lot from them about how it is that any child ever makes it to adulthood on peripheral housing estates with damp accommodation, speeding cars, and single parents who make junior hospital doctors look like idle slackers.

The national service framework for children and the Wanless report ought to make it possible to carve out a more secure place for child public health. At a local level, readers who use this book to lever child public health up local agendas will find the final chapter, with case examples of problem finding, community diagnosis, and problem solving, particularly helpful.

Helen Roberts professor of child health, Child Health Research and Policy Unit, City University, London

h.roberts@city.ac.uk

Competing interests: HR runs a research and policy unit. Although her own salary is met by the university, what is good for child public health is good for her unit, as well as good for children. 
PERSONAL VIEW

\section{If it was your brother}

\section{"D}

octor, do what you would do if it was your father or brother," requested the son of a patient who had been given a diagnosis of cancer of the pancreas with liver metastases. The patient's condition rapidly deteriorated that week, and I had a meeting with the relatives to update them and also to prepare them for the worst. But the son's request made me feel uneasy and set me thinking about events in my own family.

Two years ago I went to India to arrange medical care for my eldest brother, who was given a diagnosis of carcinoma of the tongue six years previously. Unfortunately radiotherapy had resulted in severe side effects. He had dysphagia, had become very thin, and had to be fed through a gastric tube. He had been experiencing severe pain in his throat and ear. In addition he developed lung cancer, though he seemed to have responded well to chemotherapy.

That year had been a very difficult year for him-and also for me trying to care for him from 7000 kilometres away. He used to email me everyday, describing all his symptoms, and I would reply to him after I came home from my work. Medical books and teachers certainly helped me to become a medical scientist, but he inspired me to be a doctor in the best sense of the word.

I learnt a great deal of medical ethics from my medical training, but the essence of medical ethics I learnt from this brother. When I was a medical student he used to talk about the difficulty of understanding what pain, whether physical or emotional, is in medical as well as philosophical terms. Was he a neurologist, an anaesthetist, or a psychologist?

None of them. He was a civil engineer. I learnt that to understand the patient's feelings better I needed to take off my doctor's hat sometimes and put the layman's hat on

So there I was with him in India faced with two challenges. One was a therapeutic challenge: pain relief. The second challenge was to find a doctor with a special interest in pain management in the commercially driven world of medicine in India. I talked to

We welcome submissions for the personal view section. These should be no more than 850 words and should be sent electronically via our website. For information on how to submit a personal view online, see http://bmj.com/cgi/content/full/325/ 7360/DC1/1 my brother about pain management plans for him and also various family matters. It was around midnight when he bade us goodnight and went to the toilet. Two or three minutes later we heard him clapping, which he would do if he needed attention after he lost his voice from the radiotherapy. As I was getting up from the bed he opened the toilet door, and there he was looking very frightened with blood gushing out from his nose and mouth in a projectile manner. The floor and walls were covered with blood. I rushed to hold him. I knew he was going to collapse in the next couple of seconds, not minutes. As I and the others helped him on to the floor he lost consciousness. There was panic all around-relatives were screaming and crying in shock and calling his name in the hope of bringing him back to consciousness.

There I was with my beloved brother in my hands, and I was losing him very fast in front of my own eyes. I started cardiopulmonary resuscitation, and then my son joined me in the resuscitation. He had just then finished his preregistration house officer stage, so he was better at it than I was. After 15 minutes or so of resuscitation there was no spontaneous breathing and no cardiac output. Shocked and panicked my relatives may have been, but they were probably still hoping that my son and I would succeed in our resuscitation. The ambulance arrived, though without oxygen, any resuscitation equipment, or any paramedics. So it was basically a van with a driver. My relatives insisted that we should get him to a hospital. Then it dawned on me. I came to my senses and realised that I should act as

a doctor, not as a brother. I stopped everything, asked my son to stop resuscitation, and indicated to my relatives that my eldest brother was no longer with us.

Inappropriate cardiopulmonary resuscitation? Yes, when I look back on the events I realise it was, but my strong love and emotional attachment to him caused a momentary lapse in my clinical decision making. So, when my patient's son asked me to treat his father as if he were my father or my brother, I knew that what I would have done would be the wrong intervention. But would he have known this? Of course he wouldn't have.

Macherla Radhamanohar consultant physician in general medicine for elderly people, the Royal London Hospital,London drmacherla@yahoo.co.uk
SOUNDINGS

\section{Stayin'alive with quantum physics}

Discos have always been rather an ordeal for me. I am musically dyslexic and, in the tribal society of adolescence, I should rightly have been considered disabled. Instead, at school I played rugby and read "nerdish" books. One was the incisive Chance and Necessity by Jacques Monod. Man is a machine, he asserted, and free will an illusion

Later, when I made the crossover from theoretical physics to medicine, I was surprised by the aggressive nihilism of the biologists' world view-for example, Richard Dawkins's pithy remark that "the world has precisely the properties one would expect if there is [at its root] nothing but blind, pitiless indifference."

Consciousness, it seems, is a rather tragic Darwinian epiphenomenon. Free will is likewise illusory in a universe that is merely a game of Newtonian billiard balls-its outcome determined at that first, bleak, break of time. And its author is either long gone, or certainly currently uninvolved.

My surprise partly stemmed from the vehemence and certainty of those who propounded these views. Anyone who had the temerity to believe otherwise was "scientifically illiterate."

Yet I had come from a discipline that had long since abandoned the model of the world as purely mechanistic. It was not possible to calculate the trajectory of even a simple electron without summing the wave function over the whole universe. Treat the problem as though all interactions must be local and you would simply get the answer wrong. The universe appeared interconnected in a way that left even my marijuana smoking, three lectures a month, arts student friends surprised. Biologists who knew anything about quantum mechanics maintained, not unreasonably, that quantum effects were averaged out long before reaching microscopic scales and therefore had no discernible consequences in biological systems. But this always seemed a little unlikely to me.

Maybe I am deluding myself that life has meaning and I have choice. But if so, I like the delusion, and have yet to come across a cogent argument that persuades me otherwise. I have, though, given up the belief that in a parallel universe I could dance like John Travolta. The universe is strange, but maybe not that strange.

Kevin Barraclough general practitioner, Painswick, Gloucestershire 